\title{
Temperature-Dependent Growth and Survival of Xylella fastidiosa in Vitro and in Potted Grapevines
}

Helene Feil and Alexander H. Purcell, Division of Insect Biology, University of California, Berkeley 94720-3112

\begin{abstract}
Feil, H., and Purcell, A. H. 2001. Temperature-dependent growth and survival of Xylella fastidiosa in vitro and in potted grapevines. Plant Dis. 85:1230-1234.

Xylella fastidiosa is a xylem-inhabiting bacterium that causes Pierce's disease (PD) of grapevine. Growth rates of $X$. fastidiosa in a rich liquid medium were determined by culturing methods at various temperatures. The slope of the regression line between the points of 18 and $28^{\circ} \mathrm{C}$ was similar to that reported for Escherichia coli between 12 and $30^{\circ} \mathrm{C}$ and for Erwinia amylovora between 9 and $18^{\circ} \mathrm{C}$. For three PD strains, two almond strains, and an oleander strain, $X$. fastidiosa grew fastest at $28^{\circ} \mathrm{C}$ but did not grow at $12^{\circ} \mathrm{C}$. Grape seedlings kept at $5,10,17$, or $25^{\circ} \mathrm{C}$ for 18 days, beginning 2 weeks postinoculation at $25^{\circ} \mathrm{C}$, had 230 -fold lower populations of $X$. fastidiosa when kept at $5^{\circ} \mathrm{C}$, but populations did not change significantly over time at the other temperatures. In planta populations of $X$. fastidiosa decreased 3 days after placing the seedlings at 5 and $37^{\circ} \mathrm{C}$, and subsequent samples yielded no culturable bacteria at $37^{\circ} \mathrm{C}$. Based on in vitro and in planta studies, it appears that temperatures between 25 and $32^{\circ} \mathrm{C}$ may be critical for the epidemiology of Pierce's disease because of its rapid growth rate at these temperatures, whereas temperatures below 12 to $17^{\circ} \mathrm{C}$ and above $34^{\circ} \mathrm{C}$ may affect the survival of $X$. fastidiosa in plants.
\end{abstract}

Additional keywords: Arrhenius plot, Vitis vinifera

Xylella fastidiosa (21), the cause of Pierce's disease (PD) of grapevine and other plant diseases (13), is a gramnegative, fastidious, xylem-inhabiting bacterium. $X$. fastidiosa has a wide host range $(6,13,14)$. Purcell $(18)$ provided a list of plant diseases known to be caused by $X$. fastidiosa. Wells et al. (21) compared $X$. fastidiosa $16 \mathrm{~S}$ ribosomal RNA sequences to other known $16 \mathrm{~S}$ rRNA of other bacterial species and placed $X$. fastidiosa in the gamma subgroup of the eubacteria (proteobacteria), with Xanthomonas campestris and X. maltophila as the closest relatives. The bacteria generally occur in geographical areas with mild winter climates $(11,16)$. The incidence of PD increases at the margins of its geographic distribution following warmer than average winters (11). PD symptoms appear earlier in warmer climates $(7,9)$, and our inoculations of grapevines in two cooler coastal regions and two warmer central California regions demonstrated differences in time of appearance and extent of PD symptoms in inoculated plants (H. Feil, unpublished data). The optimum growth rate for $X$. fastidiosa in vitro was determined to be approximately $28^{\circ} \mathrm{C}$ (3), which classifies $X$. fastidiosa as a

Corresponding author. Alexander H. Purcell E-mail: purcell@nature.berkeley.edu

Accepted for publication 20 August 2001.

Publication no. D-2001-1022-04R

(C) 2001 The American Phytopathological Society mesophilic bacterium. We are not aware of other published data on growth response of $X$. fastidiosa at various temperatures. Such data provide a basic understanding for studies of this pathogen's physiology and may yield useful insights into its epidemiology. Our objective was to evaluate the effects of a range of temperatures on the growth and survival of $X$. fastidiosa both in vitro and in planta.

\section{MATERIALS AND METHODS}

Bacterial strains and culture media. $X$. fastidiosa strain STL (American Type Culture Collection ATCC 700963) isolated from grapevines with PD in Napa Valley, CA, was used in all experiments. Other strains used in selected experiments were PD grape strain Temecula (ATCC 700964), collected from Temecula, CA; PD grape strain Medeiros (ATCC 700966), collected from Fresno, CA; almond leaf scorch (ALS) strains Dixon (ATCC 700965), collected in Solano County, and Oakley, (ATCC 700967) collected in Contra Costa County, CA; and an oleander leaf scorch (OLS) strain Ann1 (ATCC 700598), collected from Palm Springs, CA. Cells of $X$. fastidiosa were grown on liquid periwinkle wilt medium (PW) (5) or a modified solid version of PW with Gelrite, PWG (10) medium.

Cells of $X$. fastidiosa strain STL grown for 7 days on solid PWG medium were scraped from the medium and suspended in PW broth to a final concentration of approximately $1.5 \times 10^{9} \mathrm{CFU} / \mathrm{ml}$ determined by dilution plating. The suspension was diluted with $\mathrm{PW}$ broth to $1.5 \times 10^{3}$

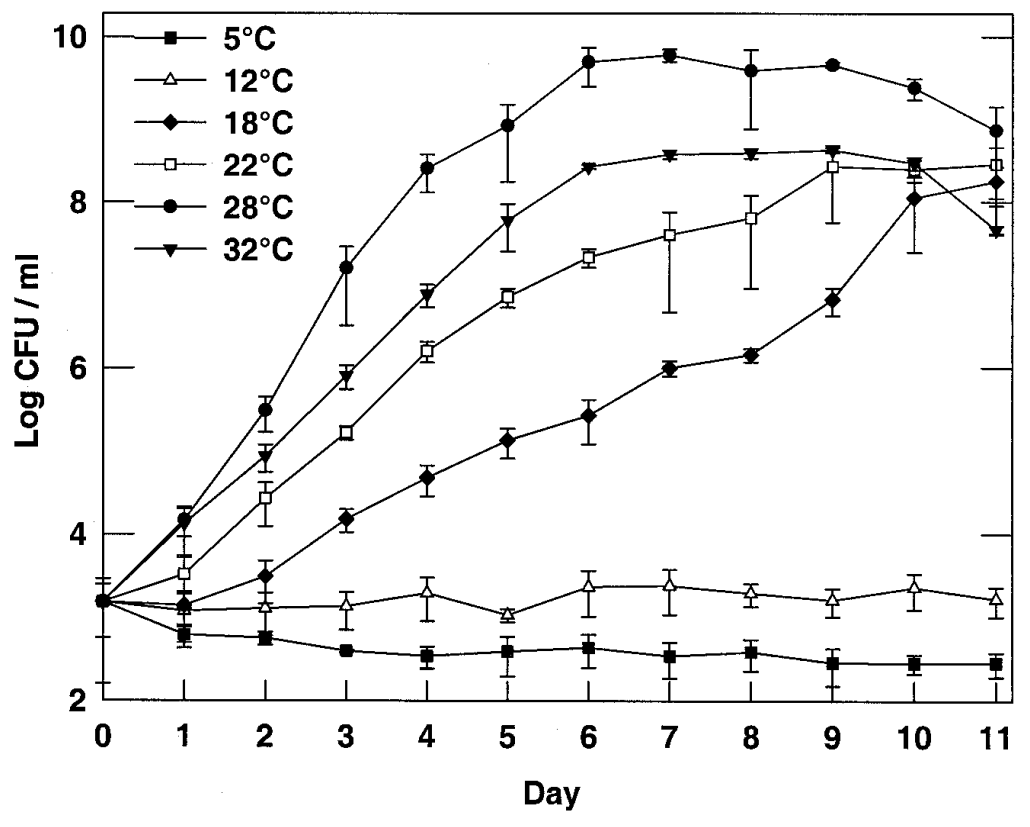

Fig. 1. Growth of Xylella fastidiosa strain STL in periwinkle wilt (PW) broth medium at different temperatures over a period of 11 days. Vertical bars represent the standard errors of the mean for two combined experiments. 
$\mathrm{CFU} / \mathrm{ml}$, which was similar to the initial concentrations $\left(10^{3}\right.$ to $10^{4}$ bacteria per $\left.\mathrm{ml}\right)$ used in studies by Billing (1) and Ruissen et al. (19). Growth studies were conducted using closed microcentrifuge tubes. Onemilliliter aliquots of the inoculum were dispensed in each of 450 microcentrifuge tubes. Glass Erlenmeyer flasks were used as a control to determine if the closed microcentrifuge tubes were oxygen-limiting. Fifty milliliters of inoculum were transferred into each of six 250-ml Erlenmeyer flasks. In two different experiments, 45 microcentrifuge tubes were placed in incubators without shaking at temperatures of $5,12,18,21,22,27,28,29,32$, and $35^{\circ} \mathrm{C}$. Two Erlenmeyer flasks with inoculum were placed on an American Rotator V Model R4140 shaker (American Hospital Supply Corp., Miami, FL) at $100 \mathrm{rpm}$ at 12,21 , and $28^{\circ} \mathrm{C}$. Every day for a period of 11 days, three tubes per temperature were selected arbitrarily for sampling. At the same time, 20- $\mu$ l samples were removed from each of the flasks and plated. The flasks were returned to their respective incubator after each sampling. A dilution series in PBS buffer was prepared for each sample. Dilutions were plated on PWG, incubated for 5 days, and number of colonies determined. This study was performed twice. A separate experiment was conducted to compare the growth of six different strains of $X$. fastidiosa (STL, Temecula, Medeiros, Dixon, Oakley, and Ann1) at $12,28,32$, and $35^{\circ} \mathrm{C}$. Microcentrifuge tubes were prepared as previously described with $1 \mathrm{ml}$ of inoculum per tube. The tubes were sampled every $24 \mathrm{~h}$ for 11 days.

We conducted additional experiments to determine if attachment of bacterial cells to the walls of the centrifuge tube caused an underestimation of populations. At each sampling of strain STL, incubated at 12, 22,28 , and $32^{\circ} \mathrm{C}$, one microcentrifuge tube was rinsed three times with $1 \mathrm{ml}$ of sterile, deionized water. After the third rinse, $1 \mathrm{ml}$ of deionized water was added to each rinsed tube and sonicated for $5 \mathrm{~min}$ at 30 W (Model 375 Vibra Cell sonicator, Sonics and Materials Inc., Danbury, CT), and the final volume was plated on PWG medium to estimate numbers of bacterial cells that may have adhered to the tubes.

Plant material and sampling. Seeds of Vitis vinifera 'Cabernet Sauvignon' grapevines collected in a commercial vineyard were sown in March 1999 in U.C. Davis soil mix. The seedlings were grown in an enclosed, heated, air-filtered greenhouse. On 6 June 1999, these seedlings were inoculated by needle puncture with the STL strain of $X$. fastidiosa in the stem above the basal leaf using the method of Hopkins and Adlerz (14).

Immediately after inoculation, seedlings ( $n=7$ ) were placed in growth chambers maintained at $5,12,18,22,28$, and $32^{\circ} \mathrm{C} \pm$ $1^{\circ} \mathrm{C}$, respectively. Dilution plating to esti- mate populations of live $X$. fastidiosa as CFU per gram of plant tissue were made using the method of Hill and Purcell (10). Because we could not detect $X$. fastidiosa in these seedlings after 2 weeks, another group of seedlings was inoculated and maintained in the greenhouse at $25^{\circ} \mathrm{C}$ for 2 weeks to allow the bacterium to spread systemically throughout the plant. After 2 weeks, the basal petiole for each seedling was sampled and cultured on PWG plates according to the method of Hill and Purcell (10). Plates were incubated for 1 week before quantifying bacterial populations within the petiole, at which time seedlings having populations of approximately $10^{8}$

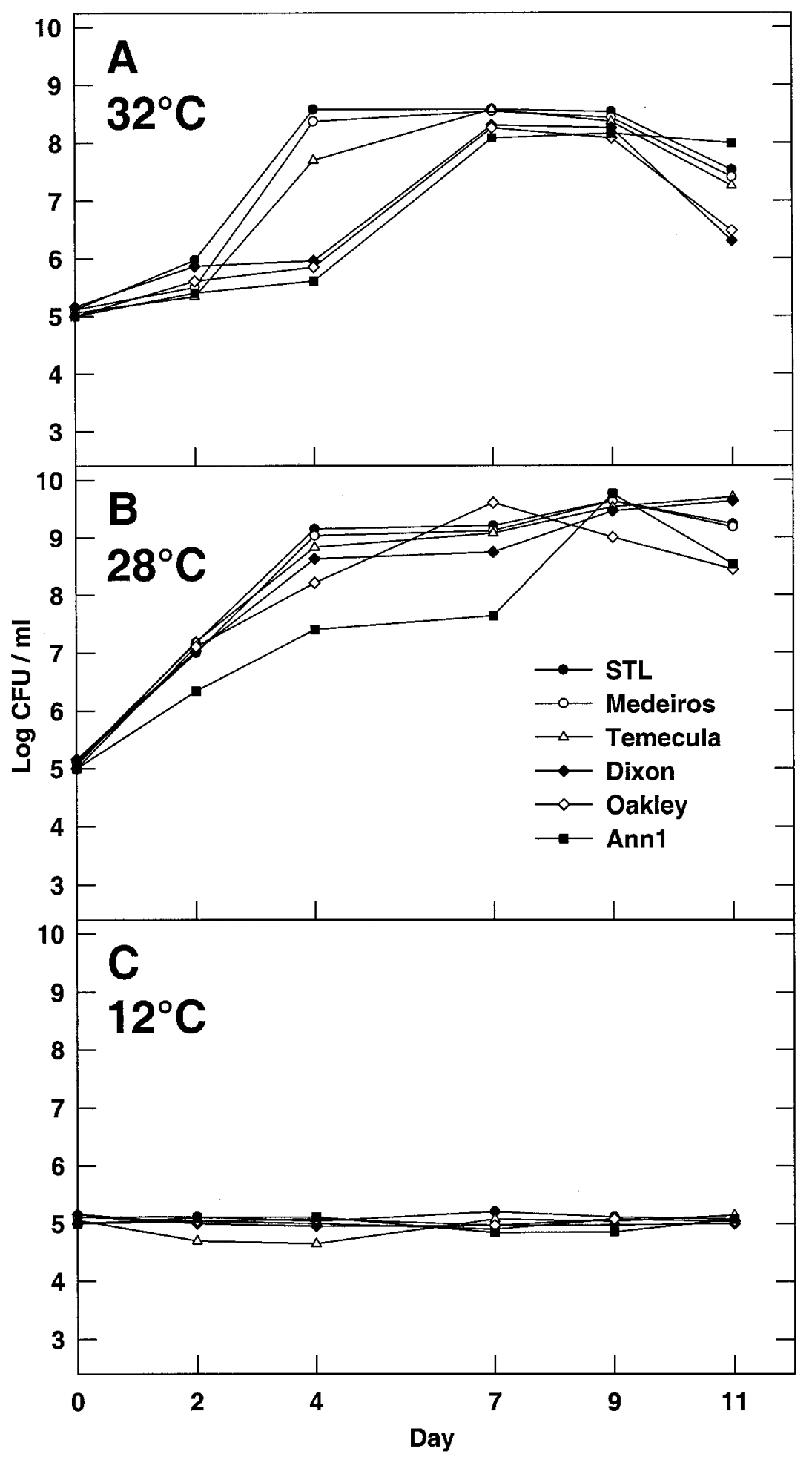

Fig. 2. Growth of Xylella fastidiosa strains STL, Temecula, Medeiros, Dixon, Oakley, and Ann1 in periwinkle wilt (PW) broth medium at $\mathbf{A}, 32^{\circ} \mathrm{C}, \mathbf{B}, 28^{\circ} \mathrm{C}$, and $\mathbf{C}, 12^{\circ} \mathrm{C}$ over a period of 11 days. Each dot represents the mean for two combined experiments. 
CFU/g of tissue were chosen for the study. This was to ensure that the bacteria had spread systemically throughout the plants. At this time (3 weeks postinoculation), the selected seedlings $(\mathrm{n}=7)$ were placed in growth chambers at 5, 12, 18, 22,28 , and $32^{\circ} \mathrm{C} \pm 1{ }^{\circ} \mathrm{C}$, respectively. After seedlings were placed in the growth chambers $\left(\mathrm{T}_{0}\right)$, the seedlings were immediately sampled by arbitrarily sampling one petiole between the basal and eighth node above the point of inoculation. Temperature was monitored in each incubator using Hobo temperature data loggers (Onset Computer Corporation, Pocasset, MA). Four inoculated seedlings for each temperature treatment were sampled every 3 days for 18 days to estimate populations of $X$. fastidiosa. The entire experiment was repeated 1 week later.
Data analysis. For the growth curves presented in Figure 1, the slope and intercept were obtained from the linear part of the exponential phase of the growth curve using the linear regression analysis of SigmaPlot 2000 (SPSS Science, Chicago, IL).

For the growth curves presented in Figure 2, the slope and intercept of $X$. fastidiosa during the exponential phase of the growth curve were determined between day 0 and day 4 for the strains STL, Medeiros, Temecula, Dixon, Oakley, and Ann1 grown at $28^{\circ} \mathrm{C}$, between day 2 and day 4 for strains STL, Medeiros, and Temecula grown at $32^{\circ} \mathrm{C}$, and between day 4 and day 7 for strains Dixon, Oakley, and Ann1 grown at $32^{\circ} \mathrm{C}$, using the linear regression analysis of SigmaPlot 2000 (SPSS Science). Differences between the $\log$

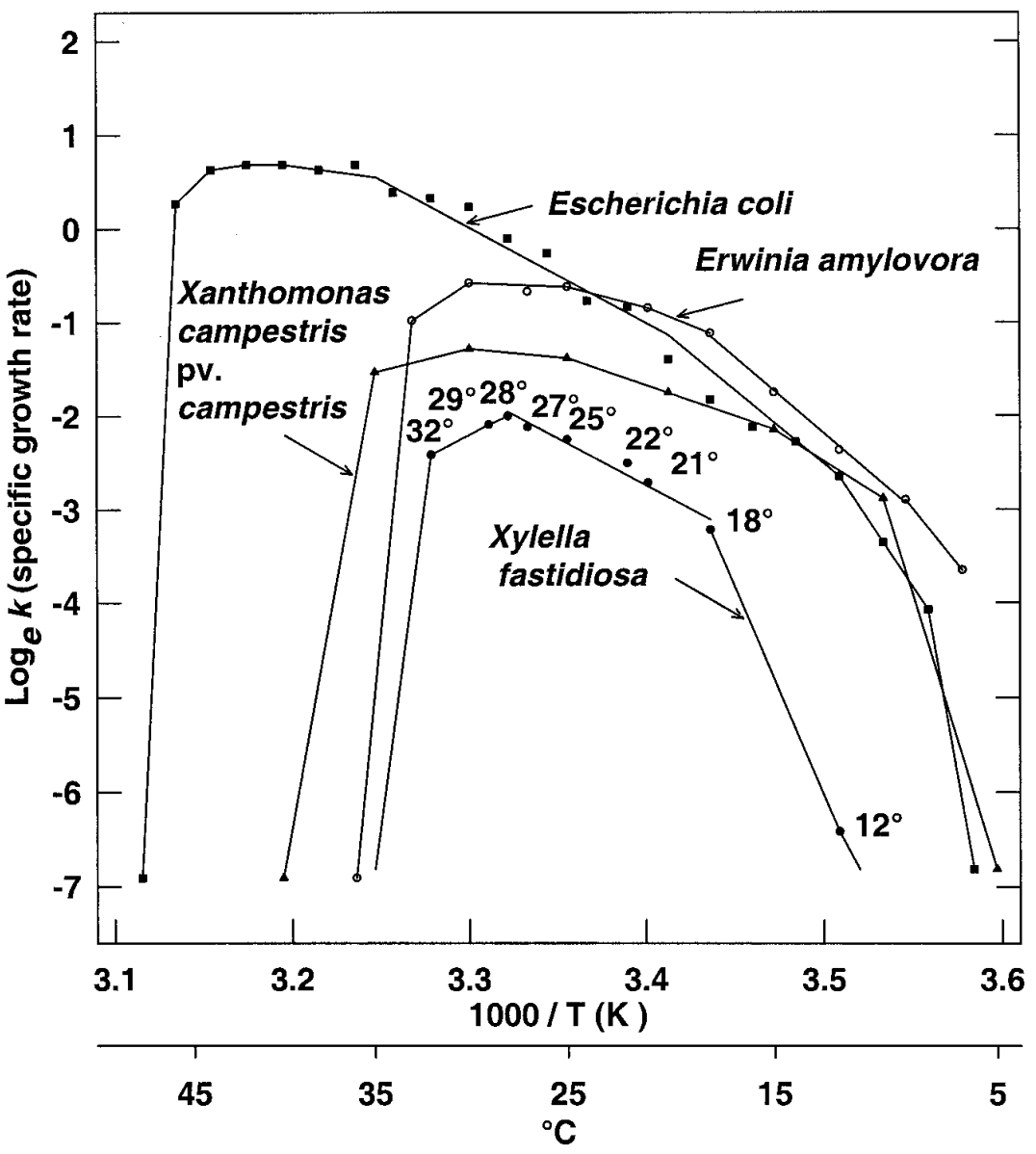

Fig. 3. Arrhenius plot of growth rates of Xylella fastidiosa strain STL (closed circles) compared with three other bacteria. Escherichia coli specific growth rate data (closed squares) as reported by Ingraham (15), Erwinia amylovora growth rate data (open circles) as reported by Billing (1), and Xanthomonas campestris pv. campestris growth rate data (closed triangles) from Ruissen et al. (19).
CFUs for the grape strains and the $\log$ CFUs for the almond and oleander strains of $X$. fastidiosa were determined using the Student's $t$ test of SigmaPlot 2000.

An Arrhenius plot (Fig. 3) for X. fastidiosa grown in PW broth was made according to the method of Billing (1), with a regression line drawn between the data points of 18 through $28^{\circ} \mathrm{C}$. To obtain the extreme ranges for the Arrhenius plot, data for growth were transformed by adding 0.001 so the data for zero observed growth could be included.

\section{RESULTS}

Populations of $X$. fastidiosa grown for up to 4 days in flasks on a shaker at 28 and $21^{\circ} \mathrm{C}$ were on average $26 \%$ greater than those grown in plastic at the same temperatures. This difference decreased to almost zero after 8 days when the cells reached the stationary phase. However, we observed no growth for either method at $12^{\circ} \mathrm{C}$ (data not presented). Also, when we sonicated the microfuge tubes used in the experiment after rinsing and filling them with deionized water, we could not detect any bacteria in the sonicated rinse water, indicating that bacterial adhesion to the microfuge tubes over the 18 days of the experiment did not affect our bacterial counts. However, it could be that rinsing and sonication is not sufficient to dislodge all attached bacteria.

Figure 1 represents the growth curves for the STL strain at 5, 12, 18, 22, 28, and $32^{\circ} \mathrm{C}$. For each curve, the doubling time (d) was determined by calculating the amount of time $(t)$ required by the cells to increase by a factor of 2 using the equation $\log y=a t+b$, where the ordinate $y$ is the number of cells per milliliter ( $\log$ $\mathrm{CFU} / \mathrm{ml}), a$ is the slope, and $b$ the intercept of the regression line. $X$. fastidiosa populations peaked in PW broth after 6 days incubation at $28^{\circ} \mathrm{C}$. After 3 days, populations of $X$. fastidiosa were about 20 times less at $32^{\circ} \mathrm{C}$ than at $28^{\circ} \mathrm{C}$. At $28^{\circ} \mathrm{C}$, populations of $X$. fastidiosa were 5 times less after 10 days than after 7 days. By 3 days, populations of $X$. fastidiosa were 100 and 1,000 times higher at $28^{\circ} \mathrm{C}$ than at 22 and $18^{\circ} \mathrm{C}$, respectively. $X$. fastidiosa populations remained almost constant at $12^{\circ} \mathrm{C}$ and declined about fivefold after 3 days at $5^{\circ} \mathrm{C}$. The specific growth rates for in vitro growth of $X$. fastidiosa for each temperature are presented in Table 1.

Figure 2 depicts the in vitro growth curves for $X$. fastidiosa strains STL, Temecula, Medeiros, Dixon, Oakley, and

Table 1. Specific growth rate $(k)$ and doubling time for Xylella fastidiosa strain STL grown at different temperatures in a rich medium

\begin{tabular}{lccccccccccccc}
\hline & \multicolumn{10}{c}{ Temperature $\left({ }^{\circ} \mathbf{C}\right)$} \\
\cline { 2 - 12 } & $\mathbf{5}$ & $\mathbf{1 2}$ & $\mathbf{1 8}$ & $\mathbf{2 1}$ & $\mathbf{2 2}$ & $\mathbf{2 5}$ & $\mathbf{2 7}$ & $\mathbf{2 8}$ & $\mathbf{2 9}$ & $\mathbf{3 2}$ & $\mathbf{3 5}$ \\
\hline$k\left(\mathrm{~h}^{-1}\right)$ & $--^{\mathrm{a}}$ & 0.0016 & 0.0400 & 0.0660 & 0.0816 & 0.1050 & 0.1203 & 0.1350 & 0.1233 & 0.0894 & - \\
Doubling time $(\mathrm{h})$ & - & - & 17.33 & 10.5 & 8.49 & 6.60 & 5.76 & 5.13 & 5.62 & 7.75 & - \\
\hline
\end{tabular}

a $-=$ no bacterial growth. 
Ann1 at 32,28 , and $12^{\circ} \mathrm{C}$, respectively. The strains Dixon, Oakley, and Ann1 grew more slowly than the PD strains STL, Temecula, and Medeiros at $32^{\circ} \mathrm{C}$ during the exponential phase. At this temperature, CFU densities after mid-logistic phase (4 days) for the almond and oleander strains Dixon, Oakley, and Ann1 were 1.7 to $3 \log$ lower than for the grape strains STL, Temecula, and Medeiros (Student's $t$ test $=$ 8.49, $P=0.001$, df = 4). Likewise, the grape strains grew faster during early exponential phase (days 0 to 4 ) at $28^{\circ} \mathrm{C}$, but one almond strain (Dixon) grew almost as fast (Fig. 2B). All strains reached approximately the same maximum population density for each temperature tested and declined thereafter. No growth was detected after incubation for 11 days at $12^{\circ} \mathrm{C}$. After 3 days incubation at 37 or $40^{\circ} \mathrm{C}$, no viable cells of any strain of $X$. fastidiosa were detected.

To complement the in vitro experiments, populations studies of $X$. fastidiosa were also performed in grape seedlings at 5, 10, $17,25,34$, and $37^{\circ} \mathrm{C}$ using the grape strain STL. For this study, we determined that the in planta detection threshold for leaf petioles was $10^{3} \mathrm{CFU} / \mathrm{g}$ according to the method of Hill and Purcell (10). Assuming the plated bacteria are randomly distributed (Poisson distribution), we would expect ( $95 \%$ confidence interval) to detect one or more CFU per $20 \mu \mathrm{l}$ of samples that had at least 200 cells per $\mathrm{ml}$. In a preliminary experiment, $X$. fastidiosa populations in grape petioles were below our detection threshold for 10 days following inoculation of grapevines that were kept at 5, 12, or $32^{\circ} \mathrm{C}$. After 7 days, we detected $X$. fastidiosa in one of seven plants at $18^{\circ} \mathrm{C}$, one of seven plants at $22^{\circ} \mathrm{C}$, and three of seven plants at $28^{\circ} \mathrm{C}$. We detected $X$. fastidiosa in all seven plants sampled at 18,22 , and $28^{\circ} \mathrm{C}$ after 10 days. Therefore, in order to measure the effect of temperatures on established $X$. fastidiosa populations, we incubated the inoculated seedlings for 2 weeks in a greenhouse heated to $25^{\circ} \mathrm{C}$ prior to being incubated at the various regulated temperatures. After plants were incubated at the various temperatures, sampling was conducted at 3-day intervals. Before transfer to various temperatures, the inoculated plants harbored populations ranging between 4 to $7 \times 10^{8} \mathrm{CFU} / \mathrm{g}$ of petiole tissue (Fig. 4). Populations of $X$. fastidiosa remained constant in plants at $17^{\circ} \mathrm{C}$ and increased fivefold at $25^{\circ} \mathrm{C}$ over 6 days. $X$. fastidiosa populations declined slightly at $10^{\circ} \mathrm{C}$ and decreased approximately 20 - and 230 -fold at 34 and $5^{\circ} \mathrm{C}$, respectively, over 18 days. The number of CFU per gram of grape petiole tissue declined 350 -fold from the initial concentration after 3 days at $37^{\circ} \mathrm{C}$, and the plants died in 3 to 6 days at this constant high temperature. In contrast to the in planta population of $X$. fastidiosa, which remained constant at $17^{\circ} \mathrm{C}$, the population of $X$. fastidiosa increased at $18^{\circ} \mathrm{C}$ in PW medium. Populations of $X$. fastidiosa increased in vitro at $18,22,28$, and $32^{\circ} \mathrm{C}$, whereas populations of $X$. fastidiosa in planta increased at $25^{\circ} \mathrm{C}$ but not at 18 or $22^{\circ} \mathrm{C}$. At $5^{\circ} \mathrm{C}$, populations of $X$. fastidiosa declined both in vitro and in planta.

The specific growth rate constant $(k)$ was calculated from the exponential phase of the growth curves of $X$. fastidiosa (Table $1)$. For this plot, the specific growth rate $k$ was determined as: $k=\left(\log _{e} 2\right) / d$, where $d$ is the mean doubling time during the exponential growth. The Arrhenius plots for three other purple proteobacteria, Escherichia coli, Erwinia amylovora, and Xanthomonas campestris pv. campestris, based on the data of Ingraham (15), Billing (1), and Ruissen et al. (19), respectively, are also given in Figure 3 for comparison. The temperature characteristic $(\mu)$ for $X$. fastidiosa was calculated from the slope of the Arrhenius plot (slope $=-\mu / R$ where $R$ is the universal gas constant) between 21 and $25^{\circ} \mathrm{C}$, where the range of temperature is normal and the relationship between growth rate and temperature is linear (1). From 21 to $25^{\circ} \mathrm{C}$, the relationship between growth rate and temperature is linear, and from the slope of this line, the temperature characteristic $(\mu)$ for $X$. fastidiosa was calculated as $2.4 \times 10^{4} \mathrm{cal} \mathrm{mol}^{-1}$. The Arrhenius plot for $X$. fastidiosa showed a narrower range of growth temperatures than E. coli, Erwinia amylovora, and $X$. campestris pv. campestris. The overall shape of the Arrhenius plot for X. fastidiosa resembles the one obtained for Erwinia amylovora. However, X. campestris, the nearest relative of $X$. fastidiosa in this study, is more tolerant of cold (below $12^{\circ} \mathrm{C}$ ) or warm (above $32^{\circ} \mathrm{C}$ ) temperatures. In general, even at optimal temperatures, the growth rate of $X$. fastidiosa is much slower than that of other typical gammasubdivision Proteobacteria. The temperature characteristic $\left(\mu=2.4 \times 10^{4} \mathrm{cal} \mathrm{mol}^{-1}\right)$ calculated between 21 and $25^{\circ} \mathrm{C}$, the normal range of temperature for the growth of $X$. fastidiosa, was similar to that of $\mathrm{Er}$ winia amylovora between 9 and $18^{\circ} \mathrm{C}$ (1) or $E$. coli between 12 and $30^{\circ} \mathrm{C}(8,15)$.

\section{DISCUSSION}

The temperature characteristic of an organism is useful for comparative purposes because it varies little over a broad range of medium richness, which can also influence growth rates (19). The number of culturable bacteria in plants declined 160 -fold after 15 days at $5^{\circ} \mathrm{C}$. This suggests that populations of $X$. fastidiosa inside grape xylem vessels decline when temperatures within xylem vessels are below $5^{\circ} \mathrm{C}$. We can expect that temperature in the xylem vessels of grape foliage, where $X$. fastidiosa resides, does not differ greatly from the surrounding air temperature, since it was found that temperature inside grape leaves does not differ

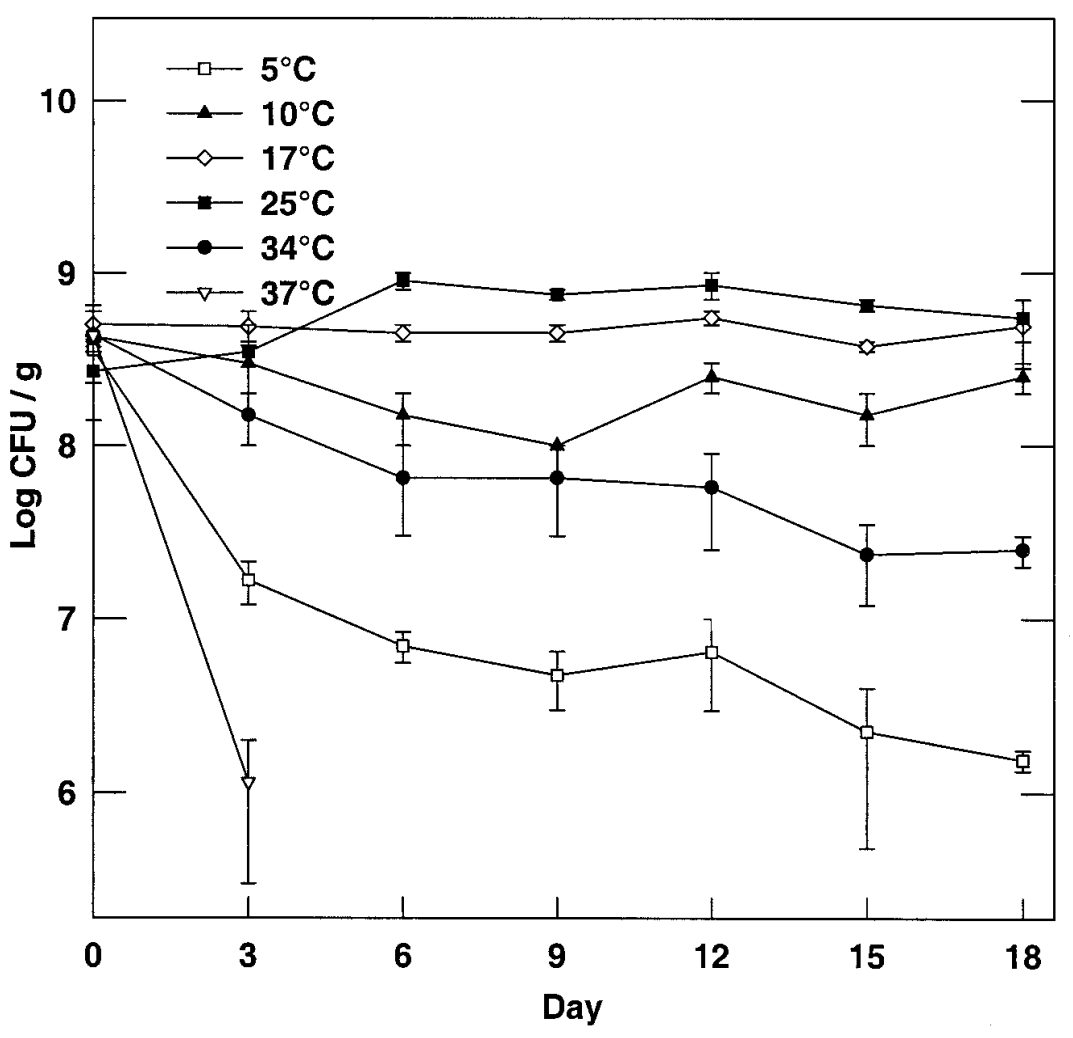

Fig. 4. Survival of Xylella fastidiosa in Vitis vinifera cv. Cabernet Sauvignon seedlings over a period of 18 days beginning 2 weeks after inoculation. Vertical bars represent the standard errors of the mean for two combined experiments. 
from the air temperature by more than 1 or $2^{\circ} \mathrm{C}(20)$.

Our studies on the effects of temperature on $X$. fastidiosa population changes in vitro used a uniform medium. However, X. fastidiosa growth in planta depends on many other factors besides temperature, for example, nutrition or possible growth stimulants or inhibitors $(2,5,12)$. Chang and Donaldson (2) showed that deletion of one amino acid reduced $X$. fastidiosa growth by $75 \%$ in their defined medium. Davis et al. (4) reported that hemin-chloride enhanced in vitro growth of $X$. fastidiosa. Hopkins (12) showed that foliar applications of indoleacetic acid, a plant growth regulator, lowered populations of $X$. fastidiosa in grapevines and prevented symptom development. Even if bacterial growth within plants cannot be modeled with temperature alone, knowing temperature effects may be helpful in understanding how temperatures can limit the growth of $X$. fastidiosa in the field. Our studies showed that populations of X. fastidiosa decline at cool but abovefreezing temperatures. We determined the minimum threshold temperature for growth of X. fastidiosa in plants to be between 17 and $25^{\circ} \mathrm{C}$. In vitro populations grew at $18^{\circ} \mathrm{C}$ but not $12^{\circ} \mathrm{C}$. The minimum threshold temperature for growth can have important epidemiological consequences. It is possible that in field conditions $X$. fastidiosa does not multiply during cool nights or at temperatures below the lower threshold temperature. It should be noted that in this study we did not measure the effect of temperature or diurnal temperatures on inducing a lag phase of growth of $X$. fastidiosa. Regions with warm day and night summer temperatures (e.g., Texas, Florida) should expect less interruption to exponential phase growth and consequently much faster growth of populations of $X$. fastidiosa in planta compared with regions with similarly warm days but much cooler nights, such as California. A lag phase of growth in $X$. fastidiosa could significantly retard bacterial growth even beyond periods of permissive growth temperatures if cool nights can induce a lag phase. Vector transmission of $X$. fastidiosa to grape during early spring months is thought to be most important in establishing chronic infections (17). The very small numbers of $X$. fastidiosa cells introduced into plants by vector transmission might decrease the likelihood of successful infection for vector inoculations that are followed by prolonged cool weather during early spring.

\section{ACKNOWLEDGMENTS}

This work was supported by the California North Coast Pierce's Disease Task Force, the American Vineyard Foundation, the Viticulture Consortium, and the Andre Tchelistcheff Scholarship fund. This study is part of the Ph.D. dissertation of H. Feil. Steven Lindow provided helpful advice for this study.

\section{LITERATURE CITED}

1. Billing, E. 1974. The effect of temperature on the growth of the fire blight pathogen, $E r$ winia amylovora. J. Appl. Bacteriol. 37:643648.

2. Chang, C. J., and Donaldson, R. C. 1993. Xylella fastidiosa: Cultivation in chemically defined medium. Phytopathology 83:192-194.

3. Davis, M. J., Purcell, A. H., and Thompson, S. V. 1978. Pierce's disease of grapevines: Isolation of the causal bacterium. Science 199:7577.

4. Davis, M. J., Purcell, A. H., and Thompson, S. V. 1980. Isolation media for the Pierce's disease bacterium. Phytopathology 70:425-429.

5. Davis, M. J., Raju, B. C., Brlansky, R. H., Lee, R. F., Timmer, L. W., Norris, R. C., and McCoy, R. E. 1983. Periwinkle wilt bacterium: Axenic culture, pathogenicity, and relationships to other gram-negative, xyleminhabiting bacteria. Phytopathology 73:15101515.

6. Freitag, J. H. 1951. Host range of Pierce's disease virus of grapes as determined by insect transmission. Phytopathology 41:920934.

7. Goodwin, P., and Purcell, A. H. 1992. Pierce's disease. Pages 76-84 in: Grape Pest Management, 2nd ed. R. C. Pearson and A. C. Goheen, eds. Division of Agriculture and Natural Resources, University of California, Oakland.

8. Herendeen, S. L., VanBogelen, R. A., and Neidhardt, F. C. 1979. Levels of major proteins of Escherichia coli during growth at different temperatures. J. Bacteriol. 139:185194.

9. Hewitt, W. B., Frazier, N. W., and Freitag, J. H. 1949. Pierce's disease investigations. Hilgardia 19:207-264.

10. Hill, B. L., and Purcell, A. H. 1995. Multiplication and movement of Xylella fastidiosa within grapevine and four other plants. Phytopathology 85:1368-1372.

11. Hopkins, D. L. 1976. Pierce's disease of grapevines. Am. Wine Soc. 8:26-27.

12. Hopkins, D. L. 1985. Effects of plant growth regulators on development of Pierce's disease symptoms in grapevine. Plant Dis. 69:944946.

13. Hopkins, D. L. 1989. Xylella fastidiosa: Xylem-limited bacterial pathogen of plants. Annu. Rev. Phytopathol. 27:271-290.

14. Hopkins, D. L., and Adlerz, W. C. 1988 Natural hosts of Xylella fastidiosa in Florida. Plant Dis. 72:429-431.

15. Ingraham, J. L. 1958. Growth of psychrophilic bacteria. J. Bacteriol. 35:75-88.

16. Purcell, A. H. 1980. Environmental therapy for Pierce's disease of grapevines. Plant Dis. 64:388-390.

17. Purcell, A. H. 1981. Vector preference and inoculation efficiency as components of varietal resistance to Pierce's in European grapes. Phytopathology 71:429-435.

18. Purcell, A. H. 1997. Xylella fastidiosa, a regional problem or global threat? J. Plant Pathol. 79:99-105.

19. Ruissen, M. A., Van Der Vossen, R. T. M., and Kocks, C. G. 1993. Growth of Xanthomonas campestris pv. campestris populations at constant and variable temperatures. Neth. J. Plant Pathol. 99:173-179.

20. Smart, R. E. 1988. Canopy management. Pages 85-103 in: Viticulture. Vol. 2, Practices. B. G. Coombe and P. R. Dry, eds. Winetitles, Adelaide, Australia.

21. Wells, J. M., Raju, B. C., Hung, H. Y., Weisberg, W. G., Mandelco-Paul, L., and Brenner, D. J. 1987. Xylella fastidiosa new-genus newspecies gram-negative xylem-limited fastidious plant bacteria related to Xanthomonas spp. Int. J. Syst. Bacteriol. 37:136-143. 